households cannot afford it and hence, they continue to remain dependent on dry wood collected from the sanctuary.

In conclusion, we strongly recommend the plantation of fast-growing firewood species, such as Dalbergia sissoo, Acacia auriculiformis, Gmelina arborea and Ailanthus excelsa in the villages adjoining the sanctuary and along the boundary of the tea plantations to meet the fuelwood needs of the people. Additionally, the use of alternative fuel sources, such as LPG, should be encouraged under government schemes, such as the Pradhan Mantri Ujjwala Yojana. Previous attempts in this direction have, however, failed because of the significant cost involved in refilling gas cylinders. Finally, appropriate alternative livelihood options need to be urgently considered for those involved in the commercial harvest of NTFP. An example of such options includes the training and recruitment of members of the local communities as forest guides by government agencies and nongovernmental organizations, as the sanctuary attracts a significant number of wildlife tourists every year. These individuals can also regularly be employed to monitor the flora and fauna of the sanctuary, important indicators of the health of this unique, though increasingly threatened, lowland rainforest patch of northeastern India.

1. Shackleton, S., Paumgarten, F., Kassa, H., Husselman, M. and Zida, M., Opportunities for enhancing poor women's socioeconomic empowerment in the value chains of three African nontimber forest products (NTFPs). Int. For. Rev., 2010, 3, 151-163.

2. Pandey, A. K., Tripathi, Y. C. and Kumar, A., Non-timber forest product for sustainable livelihood: challenges and strategies. Res. J. For., 2016, 10, 1-7.

3. Dattagupta, S. and Gupta, A., Non-timber forest product (NTFP) in northeast India: an overview of availability, utilization, and conservation. In Bioprospecting of Indigenous Bioresources of North-East India (ed. Purkayastha, J.), Springer, Singapore, 2016, pp. 978-981.

4. RosTonen, M. A. F., The role of non-timber forest products in sustainable tropical management. Holz Roh. Werkst., 2000, 58, 196201.

5. Belcher, B. M. and Vantomme, P., What isn't an NTFP? Int. For. Rev., 2003, 5, 161-168.

6. Dangi, R. B., Impact of NTFP harvesting in forest conservation. Initiation, 2008, 2, 165-171.

7. Shmatkov, N. and Brigham, T., Non-timber forest products in community development lessons from the Russian Far East. For. Chron., 2003, 79, 113-118.

8. Ticktin, T. and Shackleton C., Harvesting non-timber forest products sustainably: opportunities and challenges. In Non-timber Forest Products in the Global Context (eds Shackleton, S., Shackleton, C. and Shanley, P.), Springer, Berlin, Heidelberg, 2011, pp. 149-169.

9. Ahossou, O. D., Fandohan, B., Stiers, I., Schmidt, M. and Assogbadjo, A. E., Extraction of timber and non-timber products from the swamp forest of Lokoli (Benin): use patterns, harvesting impacts and management options. Int. For. Rev., 2017, 19, 133-144.

10. Lopez-Toledo, L., Perez-Decelic, A., Macedo-Santana, F., Cuevas, E. and Endress, B. A., Chronic leaf harvesting reduces reproductive success of a tropical dry forest palm in northern Mexico. PLoS ONE, 2018, 13, e0205178.
11. Ticktin, T. and Nantel, P., Dynamics of harvested populations of the tropical understory herb Aechmea magdalenae in old-growth versus secondary forests. Biol. Conserv., 2004, 120, 461-470.

12. Champion, S. H. G. and Seth, S. K., A Revised Survey of the Forest Types of India, Manager of Publications, Government of India, 1968.

13. Sharma, N., Sengupta, S., Boruah, D., Saikia, L. and Saikia, G., White-winged duck Asacornis scutalata in Hollangapar Gibbon Sanctuary, Assam, India. Indian Birds, 2015, 10, 121-123.

14. Sharma, N., Primates on the edge: ecology and conservation of primate assemblages in the fragmented lowland rainforests of the Upper Brahmaputra Valley, Northeastern India. Doctoral thesis, National Institute of Advanced Studies, Bengaluru and Manipal Academy of Higher Education, Manipal, 2013.

15. Ticktin, T., The ecological implications of harvesting non-timber forest products. J. Appl. Ecol., 2004, 41, 11-21.

16. Carter, J., Ndiaye, S., Pruetz, J. and McGrew, W. C., Senegal status survey and conservation action plan: West African chimpanzees. In Status Survey and Conservation Action Plan: West African Chimpanzees (eds Kormos, R. et al.), IUCN, Gland, Switzerland and Cambridge, UK, 2003, pp. 31-40.

ACKNOWLEDGEMENTS. We thank late Noren Bhuyan and Dilip Baruah for help with data collection and the Rufford Foundation, London, UK, for a grant that enabled this study. We also thank the two anonymous reviewers for their critical comments that helped improve the manuscript.

Received 20 December 2019; revised accepted 9 July 2020

doi: $10.18520 / \mathrm{cs} / \mathrm{v} 119 / \mathrm{i} 6 / 1042-1045$

\section{Genetic homogeneity in brown planthopper, Nilaparvata lugens (Stål) as revealed from mitochondrial cytochrome oxidase I}

\section{N Srinivasa $^{1}$, Subhash Chander ${ }^{2, *}$, Twinkle ${ }^{2}$ and Rahul Kumar Chandel ${ }^{2}$}

${ }^{1}$ Department of Entomology and Agricultural Zoology, Banaras Hindu University, Varanasi 221005 , India

${ }^{2}$ Division of Entomology, ICAR-Indian Agricultural Research Institute, New Delhi 110 012, India

Brown planthopper, Nilaparvata lugens (Stål) is a seasonal migrant pest in North India. The present study analyses the genetic diversity of $N$. lugens by employing a partial fragment of the mitochondrial gene encoding cytochrome oxidase I (COI) using samples from 16 different localities of India. Total of 16 fulllength COI gene sequences generated from this study

*For correspondence. (e-mail: schanderthakur@gmail.com) 
with 16 COI gene sequences retrieved from GenBank were analysed for genetic differentiation and haplotypes of $N$. lugens populations in order to determine the genetic structure. Based on the partial COI gene, high genetic homogeneity was detected in $N$. lugens populations of India and they form a single genetic group. The Tajima's $D$ test and Fu's $F$ test also support our result, and indicate recent population expansion, while the phylogenetic tree suggests that geographically distinct populations of $N$. lugens do not exist in India.

Keywords: Brown planthopper, cytochrome oxidase I, genetic homogeneity, phylogenetic tree.

THE brown planthopper (BPH), Nilaparvata lugens (Stål) is one of the serious pests of rice causing an annual yield loss worth US\$ 1.06 billion in Southeast Asia ${ }^{1}$. The major damage symptom of $N$. lugens in rice involves yellowing and drying of plants in patches, also known as 'hopper burn', , due to phloem sapping. $N$. lugensis known to transmit rice virus diseases such as rice ragged stunt (RRSV) and rice grassy stunt (RGSV) in India ${ }^{3,4}$.

Due to extremely low winter temperatures in North India and the absence of rice crop, $N$. lugens is not expected to survive in the North Indian states, but it infests the new rice crop every year ${ }^{5}$. Further, there are no alternate hosts of $N$. lugens in North India on which it can survive to complete its life cycle and to act as the nucleus population of the pest for infestation in the next season of rice. Migration of $N$. lugens during November to West Bengal $^{6}$, and two population peaks of the pest and associated insect predators were observed in net catches placed $150 \mathrm{~m}$ above ground level during May and October respectively, in the state, indicating the migratory behaviour of the pest ${ }^{7} . N$. lugens does not overwinter in temperate Asian countries such as Korea, Japan and northern China. It annually migrates into Korea and Japan during the rainy season from northern Vietnam and southern China where rice is cultivated throughout the year. It has been reported that northern Philippines is also the source for $N$. lugens migration to Japan and Taiwan $^{8,9}$. Therefore, it is possible that $N$. lugens must be migrating to North India from the southern or eastern parts of the country during May-July, immediately after the harvest of rabi rice crop in these regions, with the aid of southwest monsoon winds ${ }^{10} . N$. lugens has developed resistance to important groups of insecticides, including organophosphates and neonicotinoids, particularly imidacloprid $^{11}$ and has shown distinct virulence reactions to some rice varieties ${ }^{12}$. Therefore, the present study was undertaken to evaluate the molecular genetic structure and diversity of $N$. lugens, which is essential in designing effective management strategies for its suppression.

Mitochondrial cytochrome oxidase I (COI) is a widely used marker for understanding population structure, species identification and phylogenetic relationships of insects because of its rapid evolutionary rate, maternal inheritance and lack of introns ${ }^{13-15}$. The population genetic structure of various species such as finless porpoises ${ }^{16}$, Reticlitermes $^{17}$, Amrasca biguttula biguttula ${ }^{18}$, etc. has been revealed using mitochondrial DNA sequences ${ }^{16,17}$. In this study we examined genetic diversity among $N$. lugens populations that were collected from 16 different geographical regions of India, along with 16 sequences retrieved from NCBI, including samples from India, Pakistan and Bangladesh.

$N$. lugens populations were collected from 15 different states of India using sweep net during 2017-18 and 2018-19 rainy seasons (Table 1). The samples were transferred to glass vials containing $70 \%$ ethanol and the date and place of collection were noted. Further, samples were studied under a microscope for identification. The $N$. lugens populations were stored at $-20^{\circ} \mathrm{C}$ in the laboratory for DNA extraction and further analysis.

DNA was extracted from individual $N$. lugens using DNAeasy Blood and Tissue Kit (Qiagen GmbH, Germany), following the manufacture's protocol. The universal barcode primer used in the present study (LCO-1490-5'GGT CAA CAA ATC ATA AAG ATA TTG G-3'; HCO2198-5'-TAA ACT TCA GGG TGA CCA AAA AAT CA-3') has been described by Folmer et al. ${ }^{19}$ specific to COI. The PCR composition consists of (per $25 \mu \mathrm{l}$ ) Taq DNA polymerase (Fermentas Inc., USA) were $2.5 \mu \mathrm{l}$ of $10 \times$ PCR buffer with $2 \mu \mathrm{l}$ of $25 \mathrm{mM} \mathrm{MgCl}_{2}, 0.5 \mu \mathrm{l}$ of $10 \mathrm{mM}$ dNTPs, $0.5 \mu \mathrm{l}$ each of forward and reverse primer, IU of Taq, and $17 \mu \mathrm{l}$ of UltraPure water (Invitrogen, Thermo Fisher Scientific, USA). Thermal cycling was performed with the following conditions: pre-denaturation for $5 \mathrm{~min}$ at $94^{\circ} \mathrm{C}$ followed by 35 cycles of $30 \mathrm{sec}$ at $94^{\circ} \mathrm{C}$ (denaturation), $40 \mathrm{sec}$ at $47^{\circ} \mathrm{C}$ (annealing) and $40 \mathrm{sec}$ at $72^{\circ} \mathrm{C}$ (extension), with a final extension for $8 \mathrm{~min}$ at $72^{\circ} \mathrm{C}$. PCR products were visualized on $1 \%$ TAE-agarose gel electrophoresis (Figure 1). Single bands were purified using a QIAquick PCR purification kit (Qiagen GmbH, Germany). Purified PCR products were sequenced directly using an automated sequencer (ABI prism ${ }^{\circledR} 3730$ XL DNA analyzer; Applied Biosystems, USA) at Scigenomics Lab, Cochin, India. To verify the authenticity of the COI sequences obtained from this study, they were cross-checked with the established reference sequences of GenBank. The sequences were analysed carefully and submitted to NCBI (Table 1).

All the sequences were arranged in FASTA format for analysis using MEGA 6.0 software. Totally 32 sequences were used in diversity analysis (16 sequences of mitochondrial COI gene of $N$. lugens generated in this study and the remaining 16 sequences were retrieved from NCBI, including sequences of $N$. lugens from different localities of India, Pakistan and Bangladesh). The sequences were subjected to multiple alignments using Clustal W (ref. 20). The phylogenetic neighbor-joining tree based on Kimura-2-parameter ${ }^{21}$ distance was 
Table 1. Details of sample data used in the analysis of Nilaparvata lugens populations

\begin{tabular}{|c|c|c|c|}
\hline Accession no. & Specific collection locality & Latitude & Longitude \\
\hline MN148724 & Delhi, India & 28.7041 & 77.1025 \\
\hline MN148725 & Khonsa, Arunachal Pradesh & 26.9929 & 95.5014 \\
\hline MN148726 & Umiam, Meghalaya & 25.6768 & 91.9270 \\
\hline MN148727 & Ranichauri, Uttarkhand & 27.1750 & 85.9815 \\
\hline MN148713 & Berthin, Himachal Pradesh & 31.4188 & 76.6420 \\
\hline MN148714 & Bapatla, Andhra Pradesh & 15.9039 & 80.4671 \\
\hline MN148715 & Ranchi, Jharkhand & 23.3441 & 85.3096 \\
\hline MN148716 & Ludhiana, Punjab & 30.9010 & 75.8573 \\
\hline MN148717 & Pantnagar, Uttarkhand & 29.0222 & 79.4908 \\
\hline MN148718 & Kishanganj, Bihar & 26.0917 & 87.9384 \\
\hline MN148719 & Coimbatore, Tamil Nadu & 11.0168 & 76.9558 \\
\hline MN148720 & Varanasi, Uttar Pradesh & 25.3176 & 82.9739 \\
\hline MN148722 & Cuttack, Odisha & 20.4625 & 85.8830 \\
\hline MN148721 & Mohanpur, West Bengal & 21.8398 & 87.4232 \\
\hline MN148723 & Mahabubnagar, Telangana & 16.3841 & 78.1108 \\
\hline MN148728 & Tirupathi, Andhra Pradesh & 13.6288 & 79.4192 \\
\hline MG775040 & Panna, Madhya Pradesh* & & \\
\hline MK032794 & Solapur, Maharashtra* & & \\
\hline MG775041.1 & Madhya Pradesh, India* & & \\
\hline MK032794.1 & Pune, Maharashtra, India* & & \\
\hline MK922239.1 & New Delhi, India* & & \\
\hline BOLD:ACA8955 & Nellore, Andhra Pradesh, India* & & \\
\hline BOLD:ACA8955 & Odisha, India* & & \\
\hline MK033512.1 & Delhi, India* & & \\
\hline KX351398.1 & Umiam, Meghalaya, India* & & \\
\hline КТ879869.1 & Assam, India* & & \\
\hline BOLD:ACA8955 & Odisha, India* & & \\
\hline MK301229.1 & Faisalabad, Pakistan & & \\
\hline BOLD:ACA8955 & Chittagong, Bangladesh* & & \\
\hline BOLD:ACA8955 & Chittagong, Bangladesh* & & \\
\hline МH052644.1 & Dhaka, Bangladesh* & & \\
\hline MH052645.1 & Dhaka, Bangladesh* & & \\
\hline
\end{tabular}

* Sequences retrieved from the NCBI database.

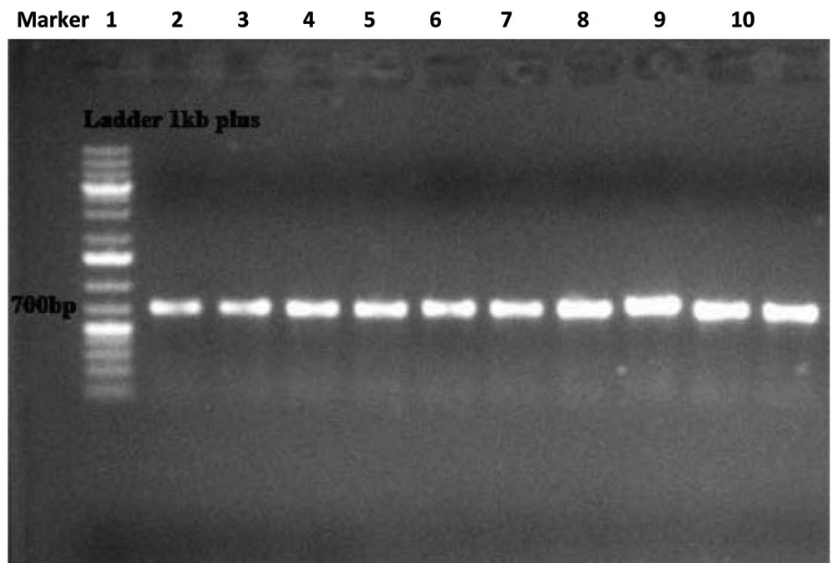

Figure 1. Nilaparvata lugens COI gene (PCR amplicon) samples showing $700 \mathrm{bp}$ product in $1 \%$ agarose gel with $1 \mathrm{~kb}$ DNA ladder.

constructed using MEGA 6 software ${ }^{22}$ with 2000 bootstrap replication. DnaSP5.10.01 was used to estimate a series of population-level parameters, including pairwise nucleotide diversity $(\pi)$ and haplotype diversity $(h)^{23}$. Neutrality tests like Tajima's $D^{24}$ and Fu's $F S^{25}$ were also per- formed using DnaSP 5.10.01 (ref. 23) for evaluating the range of historical population expansion and testing whether the sequences conformed to the expectations of neutrality.

Adults of $N$. lugens were collected from 16 different localities of 15 states of India (Table 1). Totally 32 sequences of $N$. lugens were used for the analysis, excluding two sequences of Nephotettix genus used as outgroups (MH052646.1, HM160144.1). The mean total nucleotide composition in the sequences was found to be A $31 \%$, T $36.2 \%, \mathrm{G} 12.8 \%$ and C $20 \%$. The average AT content accounted for $67.2 \%$ and $\mathrm{GC}$ for the rest $32.8 \%$ of the sequences. The bias towards AT content (67.2\%) is a general feature of the COI region in arthropods. The maximum pairwise genetic distance was found to be $0.7 \%$, and there existed only one segregating site. Further, test statistics were generated for the 32 COI sequences (Table 2). A total of four haplotypes were observed with nucleotide diversity as 0.00491 and haploid diversity as 0.7319 , indicating lower nucleotide diversity and higher haplotype diversity.

The phylogenetic neighbor-joining tree was constructed based on 32 sequences using MEGA 6.0 software $^{22}$. The 


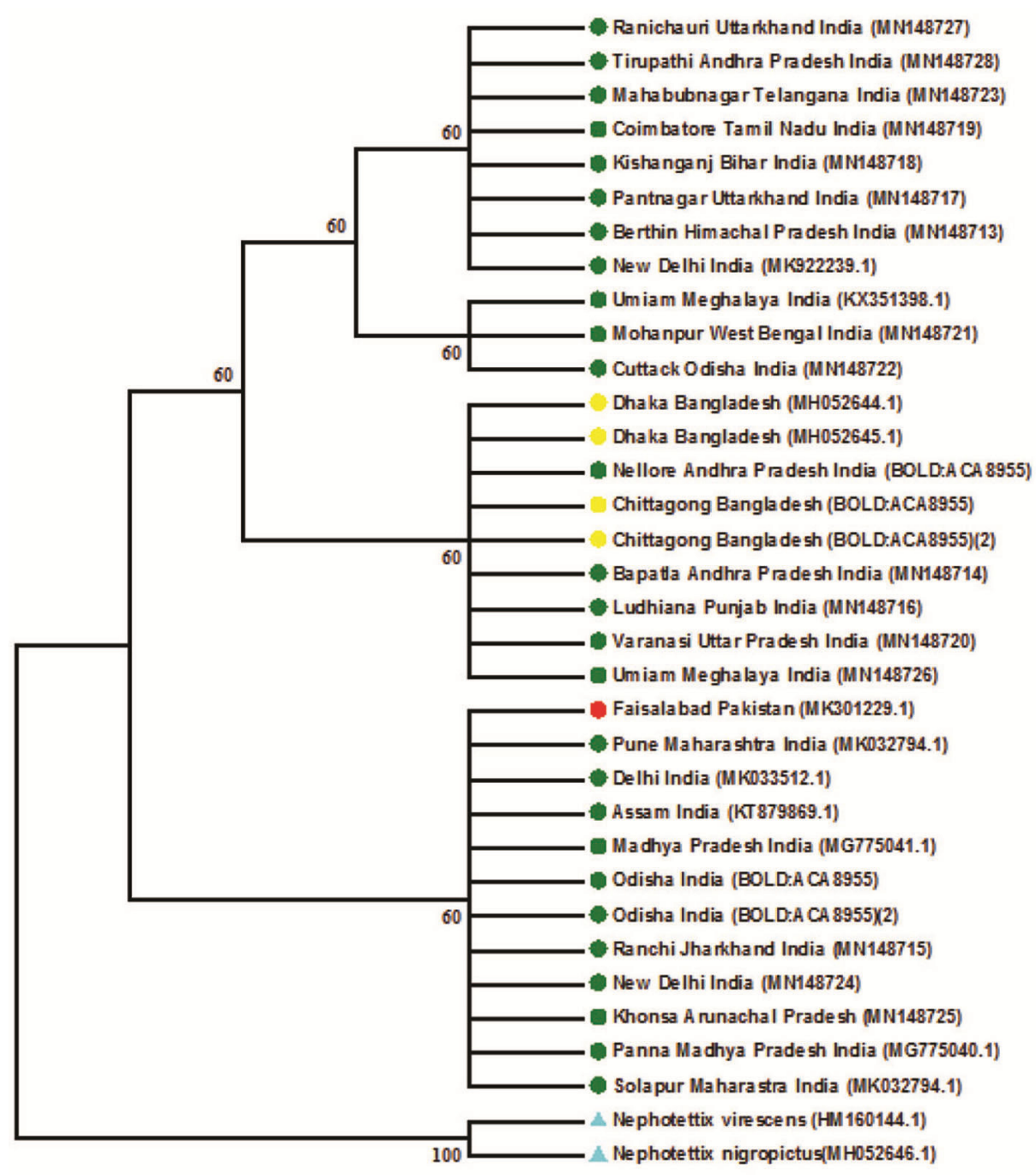

Figure 2. Phylogenetic neighbor-joining tree constructed from COI gene sequences of $N$. lugens and Nephotettix species used as outgroup.

Table 2. Genetic diversity of N. lugens populations based on COI gene sequences

\begin{tabular}{lc}
\hline Population parameters & Total population \\
\hline Sample size & 32 \\
No. of haplotypes $\left(N_{\mathrm{h}}\right)$ & 4 \\
Haplotype diversity $(h)$ & 0.7319 \\
Nucleotide diversity $(\pi)$ & 0.00491 \\
No. of segregating sites $(S)$ & 1 \\
Tajima's $D$ & -0.04056 \\
Fu's $F$ & -0.286 \\
\hline
\end{tabular}

phylogenetic tree had a total branch length of 0.33077592 base substitutions per site (Figure 2). The N. lugens populations from India, Bangladesh and Pakistan clustered in four different clades and are clearly depicted in the tree. There was no clustering of sequences from the same geographical region. However, samples from the same locality grouped together, except in case of New Delhi and
Umiam, Meghalaya samples. Further, samples from different localities of India including the southern, eastern and northern populations, were mixed in different clades without forming clades of geographical distinction (Figure 2).

$N$. lugens is a serious migratory pest of rice in tropical and temperate Asia. It is widely distributed across the region: in the west from Pakistan to northeastern Australia and in the south from the Malay Archipelago to New Guinea and the Solomon Islands to central Japan. It is a serious pest of rice in India, Bangladesh, Japan, China, Philippines, South Korea, Sri Lanka, Taiwan, Indonesia, Thailand and Vietnam ${ }^{26}$. In India it is also migratory in nature, infesting the new rice crop in North India every year and disappearing after November due to freezing temperatures in winter. However, information on genetic diversity of this pest is lacking in India.

The genetic variation in $N$. lugens populations based on 32 sequences of the COI gene in the present study

CURRENT SCIENCE, VOL. 119, NO. 6, 25 SEPTEMBER 2020 


\section{RESEARCH COMMUNICATIONS}

indicated high genetic homogeneity. The maximum genetic distance among the populations was found to be $0.7 \%$, which is below the limit of $2 \%$ generally considered for species delineation ${ }^{18,27}$. The COI sequence analysis of cotton leafhopper, Amrasca biguttula biguttula collected from cotton-growing areas of India suggested the presence of single species in the country ${ }^{18}$. Similar reports of genetic variation of $0.3-1.2 \%$ was reported among populations of tea green leafhoppers, Empoasca onukii and Jacobiasca formosana from China, Japan and Taiwan based on 16SrDNA and COI, corroborating the hypothesis that geographically separated populations of the pest represent a single species ${ }^{27}$. On the other hand, high haplotype and low nucleotide diversity observed in $N$. lugens in India suggest rapid demographic expansion of the pest from a small effective population size; similar results were reported earlier in Bicyclus anynana ${ }^{28}$. The negative values of Tajima's D and Fu's F tests in the present study indicate recent population expansion that has also been observed in Bicyclus anynana ${ }^{28}$ and in North Indian cotton leafhopper ${ }^{18}$. On the other hand, the phylogenetic tree did not depict any clustering of sequences based on geographic distinction such as North, North East and South Indian populations of $N$. lugens. However, samples from the same locality clustered together, except for a few sub-populations. The sub populations of $N$. lugens of India, Pakistan and Bangladesh were mixed in different clades without forming distinct clades. This result clearly indicates that $N$. lugens populations from different regions of India formed a single genetic group. $N$. lugens is known to migrate during two-seasons of the year: once in May when the southwest monsoon aids migration and another during October to November in eastern India due to harvest of rice crop ${ }^{7}$. This migration might be responsible for gene flow among the $N$. lugens populations that helped in maintaining their genetic homogeneity. It has been previously observed that sufficient gene flow among populations of the same species could slow down or prevent geographic differentiation and result in small population size over larger areas, as commonly observed in migratory insects or good dispensers such as Monarch butterflies Danaus plexippus ${ }^{29}$, bumblebee Bombus terrestris ${ }^{30}$, dragonflies Anax junius ${ }^{31}$ and cotton leafhopper $A$. biguttula biguttula ${ }^{18,32}$.

From the present study, it can be concluded that owing to the migratory nature of $N$. lugens, genetic homogeneity was maintained among the populations in India with less genetic variability. It is not possible to pinpoint the geographic source of $N$. lugens migration to northern India based on this level of variability. However, the future work with other molecular markers may help find the migration source of the pest. Further, studies are essential to explore the offseason survival and migratory pathway of $N$. lugens in India that will be helpful in designing regional pest management strategies for its suppression.
1. Herdt, R. W., Equity considerations in setting priories for third world rice biotechnology research. Dev. Seeds Change, 1987, 4, 19-24.

2. Sogawa, K., A change in biotype property of brown planthopper populations immigrating into Japan and their probable source areas. Kyushu Plant Prot. Res., 1992, 38, 63-68.

3. Anjaneyalu, A., Identification of grassy stunt, a new virus disease of rice in India. Curr. Sci., 1974, 43, 416-417.

4. Kulshreshtha, J. P., Anjaneyulu, A. and Padmanabhan, S. Y., The disastrous brown plant-hopper attack in Kerala. Indian Farm., 1974, 24, 5-7.

5. Srinivasa, N., Studies on seasonal phenology and climate change impact on brown planthopper dynamics with stress proteins and insecticidal efficacy perspective, $\mathrm{PhD}$ thesis, Indian Agricultural Research Institute, New Delhi, 2019.

6. Riley, J. R., Reynolds, D. R., Mukhopadyay, S., Ghosh, M. R. and Sarkar, T. K., Long-distance windborne migration of aphids and other small insects in northeast India. Eur. J. Entomol., 1995, 92, 639-653.

7. Reynolds, D. R., Mukhopadhyay, S., Riley, J. R. B., Das, B. K., Nath, P. S. and Mandal, S. K., Seasonal variation in the windborne movement of insect pests over northeast India. Int. J. Pest Manage., 1999, 45, 195-205.

8. Otuka, A., Matsumura, M., Watanabe, T. and Ding, T. V., A migration analysis for rice planthoppers, Sogatella furcifera (Horvath) and Nilaparvata lugens (Stål) (Homoptera: Delphacidae), emigrating from northern Vietnam from April to May. Appl. Entomol. Zool., 2008, 43, 527-534.

9. Otuka, A., Dudhia, J., Watanabe, T. and Furuno, A., A new trajectory analysis method for migratory planthoppers, Sogatella furcifera (Horváth) (Homoptera: Delphacidae) and Nilaparvata lugens (Stål), using an advanced weather forecast model. Agric. For. Entomol., 2005, 7, 1-9.

10. Krishnaih, N. H., A global perspective of rice brown planthopper management I crop-climatic requirement. Int. J. Mol. Zool., 2014, 4, 918-925.

11. Matsumura, M., Takeuchi, H., Satoh, M., Sanada-Morimura, S., Otuka, A., Wanate, T. and Van Thanh, D., Species-specific insecticide resistance to imidacloprid and fipronil in the rice planthoppers, Nilarparvata lugens and Sogatella furcifera in East and Southeast Asia. Pest Manage. Sci., 2008, 64, 1115-1121.

12. Claridge, M. F., Hollander, J. D. and Morgan, J. C., Variation in courtship signals and hybridization between geographically definable populations of their rice brown planthopper, Nilaparvata lugens (Stal). Biol. J. Linn. Soc., 1985, 24, 35-49.

13. Roderick, G. K., Geographic structure of insect population: gene flow, phylogeography, and their uses. Annu. Rev. Entomol., 1996, 41, 263-290.

14. Simon, C., Prati, F., Beckenbach, A., Crespi, B., Liu, H. and Flook, P., Evolution, weighting, and phylogenetic utility of mitochondrial gene severances and a compilation of conserved polymerase chain reaction primers. Ann. Entomol. Soc. Am., 1994, 87, 651-701.

15. Srinivasa, N., Subhash Chander, Rahul Kumar Chandel and Sagar, D., Gonotopus spp. parasitoids on rice plant hoppers. Indian J. Entomol., 2019, 81, 352-354.

16. Yoshida, H., Yoshioka, M., Shirakihara, M. and Chow, S., Population structures of finless porpoises (Neophocaena phocaenoides) in coastal waters of Japan based on mitochondrial DNA sequences. J. Mammal., 2001, 82, 123-130.

17. Nobre, T., Nunes, L., Eggleton, P. and Bignell, D. E., Distribution and genetic variation of Reticulitermes (Isoptera: Rhinotermitidae) in Portugal. Heredity, 2006, 96, 403-409.

18. Kranthi, S. et al., Mitochondria COI-based genetic diversity of the cotton leafhopper Amrasca biguttula biguttula (Ishida) populations from India. Mitochondrial DNA Part A, 2017, 24, 1-11. 
19. Folmer, O., Black, M., Hoeh, W., Lutz, R. and Vrijenhoek, R. DNA primers for amplifiation of mitochondrial cytochrome $c$ oxidase subunit 1 from diverse metazoan invertebrates. Mol. Mar Biol. Biotechnol., 1994, 3, 294-299.

20. Jeanmougin, F., Thompson, J. D., Gouy, M., Higgins, D. G. and Gibson, T. J., Multiple sequence alignment with ClustalX [J]. Trends Biochem. Sci., 1998, 23, 403-405.

21. Kimura, M., A simple method for estimating evolutionary rate of base substitutions through comparative studies of nucleotide sequences. J. Mol. Evol., 1980, 16, 111-120.

22. Tamura, K., Peterson, D., Peterson, N., Stecher, G., Nei, M. and Kumar, S., MEGA7: molecular evolutionary genetics analysis using maximum likelihood, evolutionary distance and maximum parsimony methods. Mol. Biol. Evol., 2011, 28, 2731-2739.

23. Librado, P. and Rozas, J., DnaSP V5: a software for comprehensive analysis of DNA polymorphism data. Bioinformatics, 2009, 25, 1451-1452.

24. Tajima, F., Statistical method for testing the neutral mutation hypothesis by DNA polymorphism. Genetics, 1989, 123, 585-595.

25. Fu, Y. X., Statistical tests of neutrality of mutations against population growth, hitchhiking and background selection. Genetics, 1997, 147, 915-925.

26. Dyck, V. A. and Thomas, B., The brown planthopper problem. In Brown Planthopper: Threat to Rice Production in Asia, International Rice Research Institute, Los Baños, Philippines, 1979, pp. $3-17$.

27. Fu, J. Y., Han, B. Y. and Xiao, Q., Mitochondrial COI and 16sRNA evidence for a single species hypothesis of E. vitis, J. formosana and E. onukii in East Asia, PLoS ONE, 2014, 9(12), e115259; doi:10.1371/journal.pone.0115259.
28. De Jong, M. A., Kesbeke, F. M. N. H., Brakefield, P. M. and Zwan, B. J., Geographic variation in thermal plasticity of life history and wing pattern in Bicyclus anynana. Climate Res., 2010, 43, 91-102.

29. Brower, A. V. Z. and Boyce, T. M., Mitochondrial DNA variation in monarch butterflies. Evolution, 1991, 45, 1281-1286.

30. Estoup. A., Solignac, M., Cornuet, J. M., Goudet, J. and Scholl, A., Genetic differentiation of continental and island populations of Bombusterrestris (Hymenoptera: Apidae) in Europe. Mol. Ecol., 1996, 5, 19-31.

31. Freeland, J. R., May, M., Lodge, R. and Conrad, K. F., Genetic diversity and widespread haplotypes in a migratory dragonfly, the common green darner Anax junius. Ecol. Entomol., 2003, 28, 413421.

32. Akmal, M., Freed, S., Dietrich, C. H., Mehmood, M and Razaq, M., Patterns of genetic differentiation among populations of Amrasca biguttula biguttula (Shiraki) (Cicadellidae: Hemiptera), Mitochondrial DNA Part A, 2018, 29(6), 897-904.

ACKNOWLEDGEMENTS. We thank Dr Chitra Srivastava (Division of Entomology, ICAR-IARI, New Delhi) for financial support to conduct this study. We also thank our colleagues at the Division of Entomology, ICAR-IARI for help.

Received 10 May 2020; revised accepted 1 July 2020

doi: $10.18520 / \mathrm{cs} / \mathrm{v} 119 / \mathrm{i} 6 / 1045-1050$ 